\title{
Effect of the essential oil of Achillea millefolium L. in the production of hydrogen peroxide and tumor necrosis factor- $\alpha$ in murine macrophages
}

\author{
Flávia Cristine Mascia Lopes ${ }^{1}$, Fernanda Paulin Benzatti ${ }^{1}$, Cleso Mendonça Jordão Junior ${ }^{2}$, \\ Raquel Regina Duarte Moreira ${ }^{3}$, Iracilda Zeppone Carlos ${ }^{* *}$
}

'Departamento de Análises Clínicas, ${ }^{2}$ Departamento de Ciências Biológicas, ${ }^{3}$ Departamento de Princípios Ativos Naturais e Toxicologia, Faculdade de Ciências Farmacêuticas, Universidade Estadual Paulista, Araraquara

* Correspondence:

I. Z. Carlos

Faculdade de Ciências Farmacêuticas

- UNESP/Araraquara

Rua Expedicionários do Brasil, 1621.

14801-902 - Araraquara - São Paulo,

Brasil.

E-mail: carlosiz@fcfar.unesp.br
Macrophages release more than one hundred compounds into the extracellular environment. Among these, there are cytokines and intermediate oxygen compounds, such as $\mathrm{TNF}-\alpha$ and $\mathrm{H}_{2} \mathrm{O}_{2}$. We evaluated the effect of the crude essential oil of Achillea millefolium L. (Asteraceae) by determining hydrogen peroxide $\left(\mathrm{H}_{2} \mathrm{O}_{2}\right)$ and tumor necrosis factor-a $(T N F-\alpha)$ release in cultures of peritoneal macrophages cells from Swiss mice. Commercial azulene was also tested for comparison with the essential oil. The macrophages viability in the presence of the oil was analyzed and the dilutions of 1:100 and 1:200 showed the best results. A mild production of $\mathrm{H}_{2} \mathrm{O}_{2}$ and a moderate liberation of TNF- $\alpha$ were observed. It was also noticed that $\mathrm{H}_{2} \mathrm{O}_{2}$ and $T N F-\alpha$ production using commercial azulene was higher than that produced by the oil. The essential oil of A. millefolium was able to stimulate peritoneal macrophages to produce $\mathrm{H}_{2} \mathrm{O}_{2}$ and $T N F-\alpha$ without causing an overproduction of these compounds. It is suggested that the essential oil can modulate macrophages activation.

\section{INTRODUCTION}

Basic research on natural substances with immunomodulating properties is performed by assays primarily carried out on the stimulation of nonspecific immunity of the innate response, such as the efficiency of macrophages (Williams, 2001).

The first cells that participate in the immunological response are macrophages. The production of cytokines and intermediate compounds of oxygen is one of their functions (Roitt, 1999). These cells respond to a variety of membrane stimulants by the production and extracellular release of a number of reactive oxygen reduction products in a coordinate sequence of biochemical reactions known as "oxidative burst" (Pick, Mizel, 1981). Studies have suggested that $\mathrm{H}_{2} \mathrm{O}_{2}$ plays an important role in the functions of macrophages (Ramasarma, 1990).

Cytokines are low-molecular-weight regulatory proteins or glycoproteins secreted by various cells in the body and among them, tumor necrosis factor- $\alpha$ (TNF- $\alpha$ ) is now accepted as a multifunctional cytokine that mediates key roles in acute and chronic inflammations, antitumor responses and infections (Palladino et al., 2003). 
Achillea millefolium L. (Asteraceae) is a plant known as Yarrow, it is native from Europe, although perfectly adapted to Brazilian environment. This plant is used in Brazilian traditional medicine to treat respiratory infections, fever and rheumatic pains. Although the essential oil displays different chemical profiles from those observed from plants of other geographical origin, the major constituents remains as: azulene, cineol, borneol, pinenes and camphor (Lorenzi, Matos, 2002).

The purpose of the present work was to study the effects of the essential oil of $A$. millefolium in cultures of peritoneal macrophage cells from Swiss mice by determination of $\mathrm{H}_{2} \mathrm{O}_{2}$ and TNF- $\alpha$. The commercial azulene was also tested to compare its effect with the essential oil obtained from the plant.

\section{MATERIAL AND METHODS}

\section{Animals}

Swiss mice (6-8 weeks old, weighting 18 to $25 \mathrm{~g}$ ) were maintained in a polycarbonate box (at $23 \pm 1{ }^{\circ} \mathrm{C}, 55$ $\pm 5 \%$ humidity, 10 - 18 circulations/h and a 12 -h light/dark cycle), with water and food available ad libitum. At least five animals were used for each experiment.

\section{Plant material}

Leaves of Achillea millefolium L. (Asteracea) were collected from the Botanical Garden at Faculdade de Ciências Farmacêuticas, Universidade Estadual Paulista, UNESP - Araraquara, São Paulo. The voucher specimen was deposited in the Herbarium of the Instituto de Biociências, Unesp - Rio Claro, under the number HRCB 35292.

\section{Commercial azulene}

A commercial azulene (Merck) sample was also tested. This sample was sonicated and sterilized. The dilution of 1:100 was used for MTT, $\mathrm{H}_{2} \mathrm{O}_{2}$ and TNF- $\alpha$ assays.

\section{Distillation and preparation of the essential oil}

The oil was obtained from the powdered leaves from Achillea millefolium L., using Clevenger-type apparatus. $200 \mathrm{~g}$ of the powdered leaves rendered about $0.6 \mathrm{~mL}$ of essential oil. It was sonicated with RPMI-1640 for 6 minutes and sterilized using a $0.45 \mu \mathrm{m}$ membrane filter. The dilutions of 1:50, 1:100 and 1:200 in RPMI-1640 were analyzed. The chromatographic profile of the essential oil was studied through a comparative thin layer chromatography and the presence of azulene was demonstrated (data not shown).

\section{Peritoneal Macrophages}

Thioglycollate-elicited peritoneal exsudate cells (PEC) were harvested from Swiss mice using $5.0 \mathrm{~mL}$ of sterile phosphate-buffered saline (PBS), $\mathrm{pH}$ 7.4. The cells were washed twice by centrifugation at $200 \mathrm{~g}$ for 5 minutes at $4{ }^{\circ} \mathrm{C}$ and resuspended in appropriate medium for each test.

\section{MTT assay for cell viability}

PEC $\left(5 \times 10^{6}\right.$ cells $\left./ \mathrm{mL}\right)$ were re-suspended in RPMI1640 containing $5 \%$ heat inactivated fetal bovine serum, $100 \mathrm{IU} / \mathrm{mL}$ penicillin, $100 \mu \mathrm{g} / \mathrm{mL}$ streptomycin and $50 \mathrm{mM}$ 2 -mercaptoethanol. The suspension $(100 \mu \mathrm{L})$ and the samples $(100 \mu \mathrm{L})$ were added to each well of a 96-well tissue culture plate and they were incubated for $24 \mathrm{~h}$. The 3-(4,5-dimethylthiazol-2-yl)-2,5-diphenyl-tetrazolium bromide (MTT) assay was performed and absorbance measured at $540 \mathrm{~nm}$ with a Multiskan Ascent ELISA reader (Labsystems, Helsinki, Finland) equipped with a $620 \mathrm{~nm}$ reference filter. Only cells and culture medium (RPMI1640 ) were used as a control that corresponds to $100 \%$ of macrophages viability.

\section{$\mathrm{H}_{2} \mathrm{O}_{2}$ measurement}

PEC $\left(2 \times 10^{6}\right.$ cells $\left./ \mathrm{ml}\right)$ were cultivated as described above and suspended in a solution containing $140 \mathrm{mmol}$ $\mathrm{NaCl}, 10 \mathrm{mmol}$ potassium phosphate buffer ( $\mathrm{pH} 7.0$ ), $5.5 \mathrm{mmol}$ dextrose, $0.56 \mathrm{mmol}$ phenol red, and $0.01 \mathrm{mg} / \mathrm{mL}$ type II horseradish peroxidase, called complete buffer. Next $100 \mu \mathrm{L}$ of this suspension was added to each of the wells of a 96-well flat-bottom tissue culture plate and exposed to $50 \mu \mathrm{L}$ of different dilutions of essential oil, commercial azulene and Zymosan at $5 \mathrm{mg} / \mathrm{mL}$ (positive control). The cells were incubated for $1 \mathrm{~h}$ at $37{ }^{\circ} \mathrm{C}$ in a $5 \%$ $\mathrm{CO}_{2}$ atmosphere. The reaction was stopped with $50 \mu \mathrm{L}$ of $5 \mathrm{~N} \mathrm{NAOH}$ and measured at $620 \mathrm{~nm}$. The results were expressed as nanomols of $\mathrm{H}_{2} \mathrm{O}_{2} / 2 \times 10^{5}$ peritoneal cells (Pick, Mizel, 1981).

\section{TNF- $\alpha$ production and assay}

For TNF- $\alpha$ production, adherent PEC was stimulated with $50 \mathrm{~mL}$ of essential oil dilutions, 
commercial azulene or lipopolysaccharide (LPS) from E. coli 0111:B4 at $10 \mu \mathrm{g} / \mathrm{mL}$, as positive control. After $24 \mathrm{~h}$ incubation, the supernatants were removed and stored at $-80{ }^{\circ} \mathrm{C}$ until assayed. L929 mouse tumor cells were used to measure TNF- $\alpha$ levels as described previously (Carlos et al., 1994).

\section{Statistical analysis}

Data are expressed as mean \pm standard deviation, and the Student's t-test (Microcal Origin 5.0) was used to determine the significance of the differences between the control and experimental groups.

\section{RESULTS AND DISCUSSION}

The effect of the essential oil of $A$. millefolium on the macrophage viability was determined by MTT assay and the 1:50 dilution showed only $30 \%$ of viable cells. Viability levels higher than 70\% were observed in the 1:100 and 1:200 dilutions. The viability of the cells in the presence of commercial azulene was 66.86 (Table I).
TABLE I - Effect of Achillea millefolium L. essential oil and commercial azulene on the viability of peritoneal macrophages. Control corresponds to $100 \%$ of viability because it contains only RPMI-1640 and cells. Each value represents the mean $\pm \mathrm{SD}$ for at least four independent experiments carried out in triplicate

\begin{tabular}{cc}
\hline Sample & Viability $(\%)$ \\
\hline Control & $100 \pm 0$ \\
\hline $\begin{array}{c}\text { Dilutions of } \\
\text { the essential oil }\end{array}$ \\
$1: 50$ & $30,73 \pm 5,04^{*}$ \\
$1: 100$ & $71,29 \pm 6,42 *$ \\
$1: 200$ & $80,57 \pm 0,47^{*}$ \\
\hline azulene & \\
$1: 100$ & $66,86 \pm 10,64 *$ \\
\hline
\end{tabular}

$* \mathrm{p}<0.05$ compared to control (RPMI-1640 and cells). Student's t-test was used.

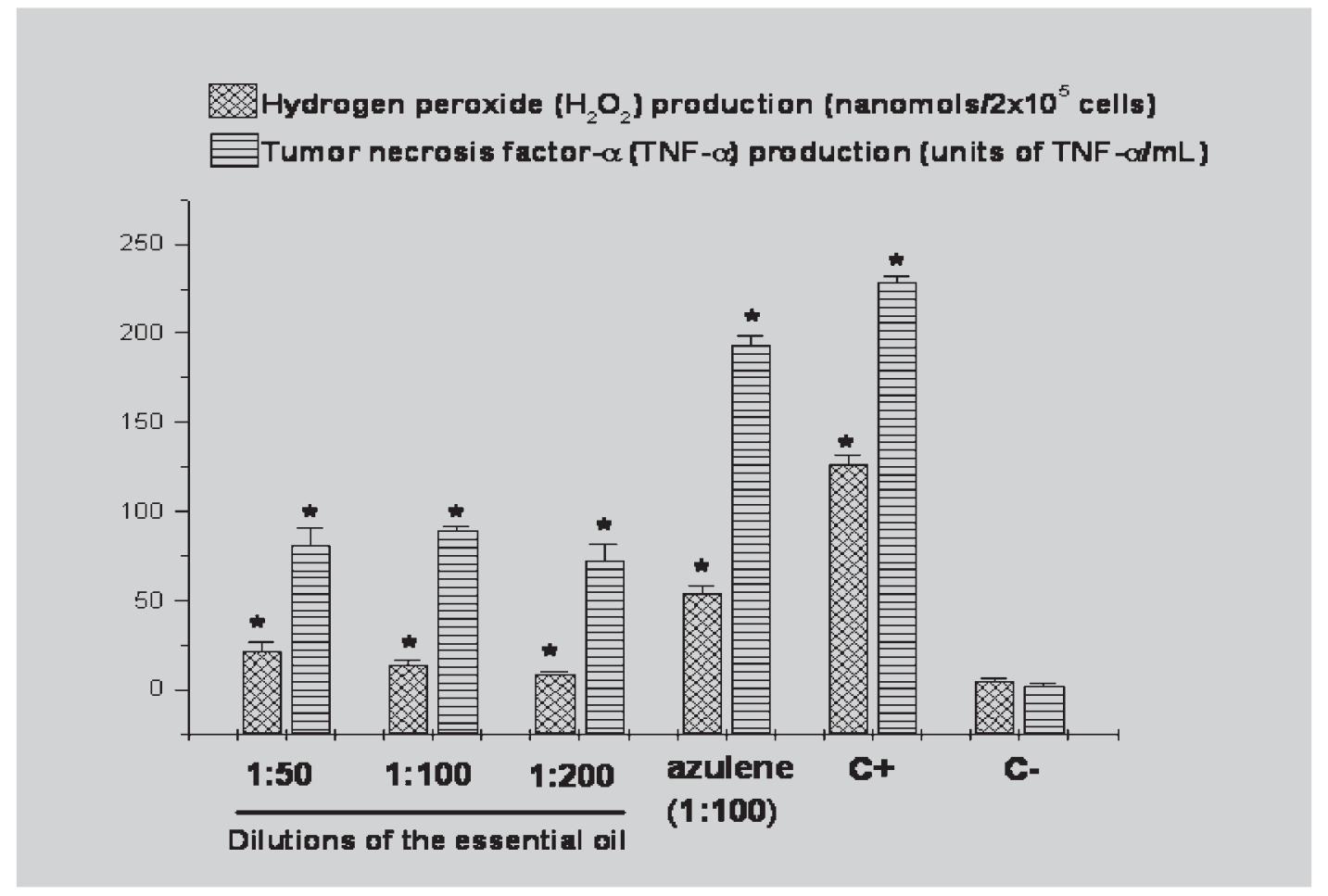

FIGURE 1 - Effect of Achillea millefolium L. essential oil and commercial azulene on hydrogen peroxide and TNF- $\alpha$ production by peritoneal macrophages culture. Three dilutions of the essential oil (1:50, 1:100 and 1:200) and commercial azulene $(1: 100)$ were tested. Zymosan $(5 \mathrm{mg} / \mathrm{mL})$ and LPS $(10 \mu \mathrm{g} / \mathrm{mL})(\mathrm{C}+)$ are the positive controls for hydrogen peroxide and TNF- $\alpha$ assays, and complete buffer plus cells and RPMI-1640 plus cells (C-) are the negative control for hydrogen peroxide and TNF- $\alpha$ assays, respectively. Data are reported as the mean \pm SD for at least four independent experiments carried out in triplicate, $* \mathrm{p}<0.05$ compared to negative controls. Student's t-test was used. 
Studies have shown that $\mathrm{H}_{2} \mathrm{O}_{2}$ has important functions in intracellular and intercellular reactions of different cells. The production of $\mathrm{H}_{2} \mathrm{O}_{2}$ in all tested samples of the essential oil was not very expressive in this work (less than $25 \mathrm{nmols} / 2.10^{5}$ cells), even though a small quantity is an important result (Figure 1). Under normal physiological conditions it is generated in small quantities and rapidly used or degraded. However long exposures and high concentrations of this mediator can destroy biological structures and lead to irreversible cell damage (Ramasarma, 1990).

Nowadays it has become apparent that the regulation of immune responses is controlled in part, by cytokines produced by macrophages. According to Figure 1, all tested samples of the essential oil produced moderate quantities of TNF- $\alpha$, around 80 Units. When the commercial azulene was tested, both $\mathrm{H}_{2} \mathrm{O}_{2}$ and TNF- $\alpha$ production were higher than the samples with plant essential oil. It is probably due to the purity of the commercial azulene.

Overproduction of pro-inflammatory cytokines and reactive oxygen species, which in adequate amounts are involved in normal and localized immune defenses, leads the development of an oxidative stress, which occurs in endotoxic shock (Víctor, De La Fuente, 2003). The production of $\mathrm{H}_{2} \mathrm{O}_{2}$ is a natural cellular process, although in high concentrations it can damage DNA, leading to cell death (Ramasarma, 1990). In this work, the production of $\mathrm{H}_{2} \mathrm{O}_{2}$ and TNF- $\alpha$ was small and moderate, respectively. These results suggest that the essential oil has a positive effect when it is utilized in the dilutions tested in this study.

Candal et al. (2003), studying the essential oil of $A$. millefolium confirmed that it possess strong anti-oxidative activity but low antimicrobial activity in vitro. Previous studies performed in our laboratory showed that essential oil of A. millefolium can induce a mild NO release $\left(14,99 \pm 0,61 \mu \mathrm{mol} / 5 \times 10^{5}\right.$ cells $)$ at a 1:100 dilution by peritoneal macrophages (Lopes et al., 2003).

Further studies are necessary to find out which Yarrow's components have a specific effect in the immune system. Nevertheless, our findings may contribute to a better understanding of beneficial effects of this folk medicine.

\section{ACKNOWLEDGEMENTS}

This work was supported by FAPESP(02/03638-1).

\section{RESUMO}

\section{Efeito do óleo essencial de Achillea millefollium L. na produção de peróxido de hidrogênio e fator de necrose tumoral- $\alpha$ por macrófagos murinos}

O efeito do óleo essencial bruto de Achillea millefolium L. (Asteraceae) foi determinado através da liberação de peróxido de hidrogênio $\left(\mathrm{H}_{2} \mathrm{O}_{2}\right)$ e do fator de necrose tumoral- $\alpha$ (TNF- $\alpha)$ por cultura de macrófagos peritoneais de camundongos Swiss. O azuleno comercial também foi testado e comparado com o óleo essencial. Macrófagos liberam mais de cem compostos biologicamente ativos. Entre esses, citocinas e compostos intermediários do oxigênio como o $\mathrm{TNF}-\alpha$ e o $\mathrm{H}_{2} \mathrm{O}_{2}$. A viabilidade dos macrófagos na presença do óleo foi analisada e as diluições de 1:100 e 1:200 do óleo essencial mostraram os melhores resultados. Pequena liberação de $\mathrm{H}_{2} \mathrm{O}_{2}$ e moderada produção de TNF- $\alpha$ também foram observadas. Contudo, maior liberação de $\mathrm{H}_{2} \mathrm{O}_{2}$ e TNF- $\alpha$ foi observada utilizando o azuleno comercial. Desse modo, observouse que o óleo essencial de A. millefolium foi capaz de estimular os macrófagos peritoneais a produzir $\mathrm{H}_{2} \mathrm{O}_{2}$ e TNF- $\alpha$ sem causar superprodução desses componentes. Sugere-se que o óleo essencial pode modular a ativação de macrófagos.

UNITERMOS: Achillea millefolium. Macrófagos. Peróxido de hidrogênio. Fator de necrose tumoral- $\alpha$. Óleo essencial.

\section{REFERENCES}

CANDAN, F.; UNLU, M.; TEPE, B.; DAFERERA, D.; POLISSIOU, M.; SÖKMEN, A.; AKPULAT, H. A. Antioxidant and antimicrobial activity of the essential oil and methanol extracts of Achillea millefolium subsp. millefolium Afan. (Asteraceae). J. Ethnopharmacol., v. 87, p. 215-220, 2003.

CARLOS, I. Z.; SGARBI, D.B.G.; ANGLUSTER, J.; ALVIANO, C.S.; SILVA, C.L. Disturbances in the production of interleukin-1-necrosis and tumor necrosis factor in disseminated murine sporotrichosis. Mycopathologia, v.127, p.189-194, 1994.

LOPES, F. C. M.; PLACERES, M. P.; MOREIRA, R. R. D.; SANTOS, L. E.; CARLOS, I. Z. Avaliação de atividade imunológica de Achillea millefolium L. ("mil-folhas"). Rev. Bras. Farmacogn., v. 13, n. 2, p. 11-13, 2003. 
LORENZI, H.; MATOS, F. J. A. Plantas medicinais no Brasil: nativas e exóticas cultivada. Nova Odessa: Instituto Plantarum, 2002. 512p.

PALLADINO, M. A.; BAHJAT, F. R.; THEODORAKIS, E. A.; MOLDAWER, L. Nat. Rev. Drug Discov., v.2, p.736746, 2003.

PICK, E.; MIZEL, D. J. Rapid microassays for the measurement of superoxide and hydrogen peroxide production by macrophages in culture using na automatic enzyme immunoassay reader. J. Immunol. Methods, v.46, p.211-226, 1981.

RAMASARMA, T. $\mathrm{H}_{2} \mathrm{O}_{2}$ has a role in cellular regulation. Indian J. Biochem. Biophys., v.27, p.269-274, 1990.
ROIT, I.; BROSTOFF, J.; MALE, D. Imunologia. São Paulo: Manole, 1999. 423p.

VÍCTOR, V. M.; DE LA FUENTE, M. Several functions of immune cells in mice changed by oxidative stress caused by endotoxin. Physiol. Res., v.52, p.789-796, 2003.

WILLIAMS, J. E. Review of antiviral and immunomodulating properties of plants of the peruvian rainforest with a particular emphasis on Uña de Gato and Sangre de Grado. Altern. Med. Rev., v.6, n.6, p. 567-579, 2001.

Recebido para publicação em 21 de dezembro de 2004. Aceito para publicação em 22 de maio de 2005. 